\title{
Editorial
}

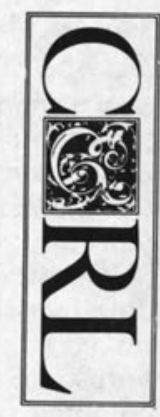

\section{Improving Quality: An Editor's Advice to Authors}

Because librarianship evolves rapidly in these technological and political times, successful librarians must share their best ideas with each other. Publishing articles in refereed journals is an established method for conveying quality information.

In this issue, Ross Atkinson predicts the continuation of the peer review system into the electronic future. In the next issue, Herb White questions whether peer reviewing for journal publications serves its quality control purposes, and Peter Hernon and his colleagues analyze the results of a comparison between papers accepted by $C \mathcal{E} R L$ and those rejected through the past decade. The purpose of this editorial is to outline some of the most common reasons that peer referees and the editor have for rejecting papers and to provide guidance for improving the quality of scholarly communications in the profession. Many articles currently rejected could contribute to solving library problems.

$C E R L$ is a double-blind refereed journal. When I receive an article, I remove the name of the author(s) and send it to one member of the editorial board and one other volunteer ACRL referee. These referees study the article, recommend acceptance, rejection, or revision, and return their results to me. If both referees accept the article, I publish it in CERL. If both reject, I write to the authors explaining the reasons for rejection, and, if appropriate, recommending submission to another journal. The most common reasons for rejecting articles include; not generalizable, "so what," poor writing, inadequate scholarship, weak statistical methodology, wrong choice of journal, and bad luck.
Not generalizable: College $\&$ Research Libraries' audience includes the 11,000 members of ACRL and others in the profession and in academe. Many submissions to $C \mathcal{E} R L$ and other journals in librarianship are case studies done in a single library often to aid in local decision making. The advantages of such papers for the author are:

- they are easy to find time to write because they relate to work

- they directly contribute to individual job performance

- they principles are easy to understand and apply

- they may be useful to other libraries who face similar problems.

However, this applicability to other institutions must be demonstrated, not assumed. At Midwinter 1993, members of the editorial board discussed how crucial it is to relate the experiences of a single library to those of the ACRL general membership. The author's challenge is to demonstrate how the work done serves as a model for others. Articles should begin with statements of generalized problems and then present the case study. In discussions and conclusions, the author must return to general college and research library applications.

"So What": A related referee question is "so what?" The author must explain why the work being discussed should reach the ACRL audience. Basic research in librarianship expands the boundaries of our knowledge about all areas of the field. Basic research may not have an immediate application to practice, but it should fill some void in the corpus of work about libraries and their users. Applied research, which includes the case studies mentioned 
above, should explain its connection to basic principles and should emphasize its general implications. CERL's peer reviewers insist that authors explain the relevance of their work.

Poor writing: One referee wrote: "The author writes poorly, as evidenced by mixed singular and plural subjects and verbs, misused words, and an incomplete sentence. The whole article just seems to be paragraphs tossed together ...I don't think it is intellectual snobbery to be appalled that a professional should submit something written this poorly." Articles must have clear organization, good grammar, and an appropriate style. Circulating a manuscript among professional colleagues is an excellent way to improve its quality and, thus, probability of publication. Members of the academic community in a number of disciplines can provide helpful criticisms. Articles should be so clearly written that laypersons can understand them.

Inadequate scholarship: It is shameful to talk to librarians about poor scholarship, but it is a major cause of rejection. All articles, even a case study, need to be sent in the context of work done in the field. Referees are knowledgeable in the areas assigned. When in doubt, they do literature searches that often turn up uncited relevant materials. Authors should use indexes and scholarly tools, do thorough searches, and regularly survey the literature of the field. "Too Many Scholars Ignore the Basic Rules of Documentation," by Janell Rudolph and Deborah Brackstone, a "Point of View" essay in the Chronicle of Higher Education (April 11, 1990), argues that incorrect citations are a national problem. Citations should be carefully checked before submission. The editorial assistant and I incline towards not accepting other articles from authors whose inadequate citations have required a great deal of our time.

Weak research and statistical methodology: Sample referee comments include:

- "It is a joke as a research methodological study"

- "The tables are terrible, and there are too many of them."
- "There is no problem statement, hypotheses, or explanation of the proposed importance of the study."

Many library practitioners have inadequate training in research methodology. However, most are located in academic institutions where help with research and statistical methods is readily available. Library resource materials on this subject are plentiful. In order to avoid having to redo anentirestudy, the researcher should consult these materials and resource persons before the study is begun.

Wrong choice of journal: Articles submitted to College \& Research Libraries should be interesting to most of the membership. If the article has an even broader appeal, then it should be submitted to American Libraries, Library Journal, or Wilson Library Bulletin. If it has a narrower appeal, then to a more specific journal-either a state or regional journal or a subject specific publication. College \& Research Libraries publishes substantive, research-oriented articles that are usually about twenty pages of double-spaced text and often have accompanying figures. CERL News publishes shorter, less formal, more practice-oriented reports. These should be sent directly to the News editor, Mary Ellen Davis. The author should compose the article with a specific journal in mind. Most journals publish editorial guidelines; CERL and CERL News' guidelines both appear in the January issues. If you have a question about the suitability of your work, you may wish to e-mail, write, or call the editors, whose addresses appear in the guidelines.

Bad luck: Two examples of bad luck are to send in a paper on the same subject that the editor has just accepted a long paper on or to submit work in a special area of interest to the referees or the editor. I find that the referees and I are more critical of works in areas we've written about. We know the literature better and our ideas are more concrete than in areas of less expertise. However, often our interest level is high, and we generate lengthy suggestions for revisions and then publish the revised work. Any author who follows the advice given in 
the first six points has little to worry about in this final one.

Librarianship, a dynamic, rapidly evolving field in the Information Age, needs to share the ideas of its best minds. Quality journal publication is a proven method for meeting this need. Like other fields discussed in White's article, quantity is not the most pressing requirement-quality is. Authors must:
- think about professional problems that require solutions,

- study them with well-designed methodologies, and

- explain the applicability of the study to the problem in clear prose.

Articles so conceived and constructed can improve the quality of library literature and librarianship itself.

GLORIANA ST. CLAIR

\section{IN FORTHCOMING ISSUES OF COLLEGE \& RESEARCH LIBRARIES}

Scholarly Publication, Academic Libraries, and the Assumption That These Processes Are Really Under Management Control

Herbert S. White

Cooperative Collection Development at the Research Triangle University Libraries: A Model for the Nation

Patricia Buck Dominguez and Luke Swindler

Publication in College \& Research Libraries: Accepted, Rejected, and Published Papers, 1980-1991

Peter Hernon, Allen Smith, and Mary Bailey Croxen

Interdisciplinary Work and the Information Search Process: A Comparison of Manual and Online Searching

Laura M. Bartolo and Timothy D. Smith 
World Encyclopedia of Library and Information Services, Third Edition

Robert Wedgeworth, editor-in-chief

Alone in its field, the World Encyclopedia is the fundamental one-volume reference source on libraries and librarianship worldwide. Thousands of professionals refer to its historical and theoretical overviews, nation-by-nation surveys, and coverage of the most advanced technologies of the information and bibliographic communities.

With some 340 articles by more than 300 contributors from all parts of the globe, the World Encyclopedia is a million word resource on the history, structure, concepts, practice, research, training, institutions, and people of its fields.

Features include:

$\downarrow$ a full-color pictorial on five of the world's most magnificent libraries

$\downarrow$ hundreds of black-and-white illustrations

$\downarrow$ comprehensive index

$\downarrow$ statistics updated to 1990

$\downarrow$ new bibliographic sources for reprinted articles

\section{Special Pre-Publication Offer!}

Order before July 31,1993 and receive $20 \%$ off the list price!

World Encyclopedia of Library and Information Services, Third Edition \$200.00cl. Alpprox. 1,200p. ISß.N0-8389-0609-5

ALA Order Code 0609-5-0011

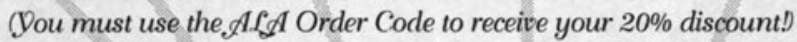

Don't delay, place your order today!

Call 1-800-545-2433 and press 7.

ALA Books

American Library Association

50 East Huron Street

Chicago, IL 60611

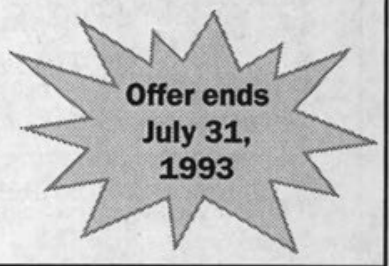

